\title{
Factors Affecting the Success of Multi Drug Resistance (MDR-TB) Tuberculosis Treatment in Residential Surakarta
}

\author{
Elisabeth Ria Widyasrini, ${ }^{1,2)}$, Ari N Probandari3), Reviono4) \\ 1)Public Health Center, Klaten \\ ${ }^{2)}$ Masters Program in Family Medicine, Universitas Sebelas Maret \\ 3) Faculty of Medicine, Universitas Sebelas Maret \\ 4)Department of Pulmonology and Respiratory Medicine, Dr. Moewardi, Surakarta
}

\begin{abstract}
Background: Tuberculosis (TB) is a global public health concern. The new challenge in TB control is the development of TB multi drug resistance (MDR-TB). Indonesia ranks 8th highest in the incidence of MDR-TB with 8,900 MDR-TB cases in 2004. A case was defined as MDR-TB if the Mycobacterium tuberculosis was resistant to rifampicin dan isoniazid. This study aimed to determine the factors affecting the success of multi drug resistance (MDR-TB) tuberculosis treatment.

Subjects and Method: This was an analytic observational study using case control design. The study was conducted at Dr. Moewardi Hospital, Surakarta, Central Java, Indonesia, in October 2014. The case population were MDR-TB patients visiting Dr. Moewardi Hospital for TB treatment from 2011 to October 2014. A sample of 84 TB cases consisting of 26 patients who dropped out, defaulted, or died, and 58 patients who successfully completed TB treatment, were selected for this study. The independent variables were sex, age, marital status, nutrional status, education, employment status, drug side effect, family support, and distance to health facility. The dependent variable was success of treatment. The data were collected by direct interview, questionnaire, and medical record. Logistic regression was employed for data analysis.

Results: Age $(\mathrm{OR}=0.93 ; 95 \% \mathrm{CI}=0.88$ to $0.97 ; \mathrm{p}=0.004)$ and drug side effect $(\mathrm{OR}=6.84 ; 95 \%$ $\mathrm{CI}=2.50$ to $18.74 ; \mathrm{p}<0.001)$ affected the success of $\mathrm{TB}$ treatment and statistically significant. Sex $(\mathrm{OR}=0.66 ; 95 \% \mathrm{CI}=0.17$ to $2.58 ; \mathrm{p}=0.556)$, education $(\mathrm{OR}=0.90 ; 95 \% \mathrm{CI}=0.52$ to $1.58 ; \mathrm{p}=0.724)$, employment status $(\mathrm{OR}=0.87 ; 95 \% \mathrm{CI}=0.59$ to $1.28 ; \mathrm{p}=0.485)$ affected the success of $\mathrm{TB}$ treatment but statistically not significant.
\end{abstract}

Conclusion: Success of TB treatment is affected by age and drug side effect.

Keywords: success of treatment, tuberculosis, multi drug resistance.

\section{Correspondence:}

Elisabeth Ria Widyasrini. Public Health Center, Klaten, Central Java.

Email: lisabalkesmasklaten@gmail.com, mobile: +628990833108.

\begin{tabular}{l}
\hline BACKGROUND \\
Tuberculosis (TB) disease is still a global \\
health problem because it is the second \\
deadly infectious disease after HIV / AIDS \\
infection (WHO, 2015), even though \\
control efforts with the Direct Observed \\
Treatment Shortcourse (DOTS) strategy \\
have been implemented in several countries \\
since 1995. In 2015, the context of the \\
Millennium Development Goals (MDGs) \\
has shifted to a new era of Sustainable De-
\end{tabular}
has shifted to a new era of Sustainable De- velopment Goals (SDGs) which are applied to reduce morbidity and mortality due to TB disease (WHO, 2015). The World Bank stated that the DOTS strategy as a health intervention is cost effective, given that TB treatment takes 6 to 8 months of treatment, which requires a high cost. Tuberculosis can attack all ages, both adults and children. About $75 \%$ of those infected with TB are of productive age (15 to 50 years) 
and $6 \%$ of children (Department of health, 2014).

It is estimated that there are 9.6 million people worldwide in 2014 infected with $\mathrm{TB}, 5.4$ million men, 3.2 million women and 1 million children. Globally, $12 \%$ of 9.6 million TB sufferers also suffer from HIV AIDS (WHO, 2015). Of the 9.6 million new TB cases in 2014, $58 \%$ were in Southeast Asia and the Western Pacific region. India, Indonesia and China have the largest number of TB cases, namely $23 \%, 10 \%$ and $10 \%$ of the global total (WHO, 2015).

Indonesia is a country with a high $\mathrm{TB}$ prevalence. According to the WHO report in 2015. Indonesia ranked second in the world with a total of 429 thousand TB patients (WHO, 2015). The prevalence of Indonesian population diagnosed with pulmonary TB by health personnel in 2013 was 0.4 percent, not different from 2007. Five provinces with the highest pulmonary TB were West Java (0.7\%), Papua (0.6\%), DKI Jakarta (o.6\%), Gorontalo (0.5\%), Banten (0.4\%) and West Papua (0.4\%) (Ministry of Health RI, 2013).

A new challenge in the treatment of $\mathrm{TB}$ in the world and Indonesia is the beginning of an increase in cases of Multi Drug Resistance TB (MDR-TB) which reaches $3.5 \%$ (WHO, 2015) and makes the problem of TB disease need special attention. About 480,00o cases of MDR TB (MDR-TB) are estimated to occur in 2014, only about a quarter of them were detected and reported. Globally, an estimated 3.3\% of new TB cases and $20 \%$ of TB cases recur to MDR-TB. Globally, only 50\% of MDR TB patients are successfully treated. In 2014, an estimated 190,000 people with MDR-TB died (WHO, 2015).

The estimated prevalence of MDR TB in Indonesia in 2004 was 8,900 cases. Two percent of MDR TB cases are estimated to come from new TB cases and $14.7 \%$ of TB cases who receive repeat treatment. Based on the 2010 MDR TB Global Report, Indonesia is a country with MDR TB burden no. 8 in the world with an estimated new cases of MDR TB of 8900 people per year.

Indonesia received an approval from the Green Light Committee in 2007 to treat 100 patients with MDR TB. Since August 2009, Indonesia began treatment of MDR TB patients in 2 locations, namely the Persahabatan Hospital, Jakarta and Dr. Soetomo, Surabaya (Burhan, 2010). In 2010, the development has begun in several other regions, namely Malang and Surakarta (Ministry of Health RI, 2011.)

MDR TB is a case of tuberculosis with resistance to at least 2 types of the most potent anti-tuberculosis drugs, namely Rifampicin and Isoniasid (INH) together or accompanied by other first-line OAT resistance such as Pyrazinamide, Ethambutol and Streptomycin (Ministry of Health RI, 2014). Many factors have led to the increasing number of MDR-TB cases. The purpose of this study is to analyze the factors that influence the successful treatment of MDR TB patients in the ExSurakarta Residency.

\section{SUBJECTS AND METHOD \\ 1. Study Design \\ This was an analytic observational with a case control design. This study aimed to determine the factors that influence the success of MDR TB patient treatment.}

\section{Population and Subjects}

The case population was MDR TB patients who went to Dr. Moewardi, Surakarta in 2011 (early MDR TB program at Dr. Moewardi Hospital) until October 2014 living in the former Surakarta Residency.

Subjects of the case group were patients with MDR TB aged $\geq 14$ years who dropped out, failed treatment, or died 
amounting to 26 people. The subjects of the control group were TB patients aged $\geq 14$ years who had successfully completed treatment for about 58 people.

The exclusion criteria of this study subject were patients who refused to participate in the study, patients residing outside the former Surakarta Residency, patients moved to a residence outside the former Surakarta Residency, patients were not tracked and the patients whose medical record was missing or incomplete.

\section{Study Variables}

The dependent variable was the success of the treatment. The independent variables were gender, age, education, distance of residence of MDR TB patients with health, work, marital status, family assistance, drug side effects, family support and nutritional status.

\section{Operational Definitions}

The operational definition of treatment success was MDR TB patients who have completed treatment and are declared as cured or complete the treatment.

Education level was defined as a programmed and structured education that takes place at the school that is taken by the study subjects.

The distance of residence with health facilities was the distance traveled by MDR TB patients from home to health facilities.

Treatment accompaniment was the presence or absence of the accompanying family when the patient visits health facilities. Side effects of treatment were effects that cause other complaints after the patient takes the drug given.

Family support was the assessment of study subjects on the attitudes and behavior of family members during the treatment process.

Nutritional status was the size of the patient's Body Mass Index (BMI) measured by height and weight with the formula $\mathrm{BB}$ (kg) /height (meters).

\section{Study Instruments}

Data on the success of MDR TB treatment, drug side effects, and nutritional status were measured using secondary data (review of medical record documents). Other data were obtained using questionnaires and interviews.

\section{Data Analysis}

Univariate, bivariate data analysis were conducted with logistic regression test and knowing the risk ratio (odds ratio) and the multivariate was done using logistic regression test.

\section{RESULTS}

\section{Characteristic of the subjects}

The frequency distribution of the case and control group study subjects is presented in Table 1. The study subjects who were male in the case group amounting to 15 people (57.7\%) experienced treatment failure /died /dropped out. Subjects in the control group or successful in treatment were mostly female, amounting to 30 people (51.7\%).

Most of the study subjects in the case group were junior high school and senior high school graduates and there were eight for each (30.8\%). Most of the study subjects in the control group were senior high school graduates of 26 people (44.8\%). A total of 10 people (38.5\%) in the case group worked as laborers. A total of 26 people (44.8\%) in the control group did not work.

Most of the study subjects in the case group lived $10 \mathrm{~km}$ from the place or about 14 people (53.8\%). There were 23 people $(39.7 \%)$ in the case group who live $\geq 10 \mathrm{~km}$.

Study subjects in the case group consist of mostly married people for about 22 people (84.6\%). Most of the study subjects in the married status control group were 51 people (87.9\%). There were study subjects whose status was widow / widower 
in the case group and the control group of 1 person each.

Study subjects in the case group received family assistance for about 25 (96.2\%). Most of the control groups received family assistance of 54 people (93.1\%). Most of the study subjects experienced a moderate level of treatment side effects

Table 1. The Distribution of case and control group frequency

\begin{tabular}{|c|c|c|c|c|c|c|c|}
\hline \multirow{3}{*}{ Variable } & \multirow{3}{*}{ Categoriy } & \multicolumn{4}{|c|}{ The Success of a Treatment } & \multirow{2}{*}{\multicolumn{2}{|c|}{ Total }} \\
\hline & & \multicolumn{2}{|c|}{ Failed/ Died/ DO } & \multicolumn{2}{|c|}{ Treated } & & \\
\hline & & $\mathbf{N}$ & $\%$ & $\mathbf{n}$ & $\%$ & $\mathbf{n}$ & $\%$ \\
\hline \multirow[t]{2}{*}{ Gender } & Male & 15 & 57.7 & 28 & 48.3 & 43 & 51.2 \\
\hline & Female & 11 & 42.3 & 30 & 51.7 & 41 & 48.8 \\
\hline \multirow{6}{*}{$\begin{array}{l}\text { Educational } \\
\text { background }\end{array}$} & No formal & & & & & & \\
\hline & education & 3 & 11.5 & 3 & 5.2 & 6 & 7.1 \\
\hline & PS & 8 & 30.8 & 18 & 31.0 & 26 & 31.0 \\
\hline & JHS & 7 & 26.9 & 9 & $15 \cdot 5$ & 16 & 19.0 \\
\hline & SHS & 8 & 30.8 & 26 & 44.8 & 34 & 40.5 \\
\hline & Bachelor degree & $\mathrm{o}$ & 0.0 & 2 & 3.4 & 2 & 2.4 \\
\hline \multirow[t]{7}{*}{ Occupation } & Not working & 6 & 23.1 & 23 & 39.7 & 29 & 34.5 \\
\hline & Farmer & 1 & 3.8 & 5 & 8.6 & 6 & 7.1 \\
\hline & Labor & 10 & 38.5 & 10 & 17.2 & 20 & 23.8 \\
\hline & Seller & 2 & 7.7 & 7 & 12.1 & 9 & 10.7 \\
\hline & Employee & 4 & $15 \cdot 4$ & 6 & 10.3 & 10 & 11.9 \\
\hline & Etc. & 3 & 11.5 & 7 & 12.1 & 10 & 11.9 \\
\hline & $<5 \mathrm{~km}$ & 7 & 26.9 & 13 & 22.4 & 20 & 23.8 \\
\hline Residence & $5-10 \mathrm{~km}$ & 5 & 19.2 & 16 & 27.6 & 21 & 25.0 \\
\hline Distance & $\geq 10 \mathrm{~km}$ & 14 & 53.8 & 29 & 50.0 & 43 & 51.2 \\
\hline \multirow[t]{3}{*}{ Marital status } & Single & 3 & 11.5 & 6 & 10.3 & 9 & 10.7 \\
\hline & Married & 22 & 84.6 & 51 & 87.9 & 73 & 86.9 \\
\hline & Widow/widower & 1 & 3.8 & 1 & 1.7 & 2 & 2.4 \\
\hline \multirow{5}{*}{$\begin{array}{l}\text { Family } \\
\text { assistance } \\
\text { Side effects }\end{array}$} & No assistance & 1 & 3.8 & 4 & 6.9 & 5 & 6.0 \\
\hline & Assistance & 25 & 96.2 & 54 & 93.1 & 79 & 94.0 \\
\hline & Light & 3 & 11.5 & 24 & 41.4 & 27 & 32.1 \\
\hline & Medium & 12 & 46.2 & 30 & 51.7 & 42 & 50.0 \\
\hline & Serious & 11 & 42.3 & 4 & 6.9 & 15 & 17.9 \\
\hline \multirow{3}{*}{$\begin{array}{l}\text { Nutritional } \\
\text { status }\end{array}$} & Thin & & & & & & \\
\hline & & 11 & 42.3 & 27 & 46.6 & 38 & 45.2 \\
\hline & Normal & 15 & 57.7 & 31 & 53.4 & 46 & 54.8 \\
\hline
\end{tabular}

\section{Univariate Analysis}

Table 2 shows the results of the univariate analysis. The results of univariate analysis showed that the SD value was smaller than the mean value on the variables of age and consisting of 12 people (46.2\%) in the group of cases and there were about 30 people (51.7\%) in the control group.

Most of the study subjects were underweight, consisting of 15 people (57.7\%) in the case group and 31 people (53.4\%) in the control group.

family support. These results indicate that age and family support data are representative. The youngest age of this study subject was 19 years old and the oldest was 80 years old. 
Widyasrini et al./ Factors Affecting the Success of Multi Drug Resistance

Table 2. The result of univariate analysis

\begin{tabular}{lcccc}
\hline \multicolumn{1}{c}{ Variable } & Mean & SD & Minimum & Maximum \\
\hline Age & 42.76 & 13.68 & 19 & 80 \\
Family support & & & & \\
$\quad$ Emotional support & 14.00 & 1.50 & 10 & 16 \\
Appreciation support & 15.54 & 0.98 & 12 & 16 \\
Informational support & 14.89 & 1.43 & 10 & 16 \\
Intrumental support & 14.31 & 1.83 & 9 & 16 \\
\hline
\end{tabular}

\section{Bivariate Analysis}

Bivariate analysis was used to analyze the effect of each factor namely gender, age, education, occupation, distance of residence, marital status, family assistance, side effects of medication, family support, and nutritional status on the success of MDR TB treatment.

Table 3 shows that treatment side effects have an effect on increasing the success of MDR TB treatment and it was statistically significant $(\mathrm{OR}=4.83 ; 95 \% \mathrm{CI}=$

Table 3. The result of bivariate analysis

\begin{tabular}{|c|c|c|c|c|}
\hline \multirow{2}{*}{ Variables } & \multirow{2}{*}{ OR } & \multicolumn{2}{|c|}{$95 \%$ CI } & \multirow[b]{2}{*}{$\mathbf{p}$} \\
\hline & & Lower level & Upper level & \\
\hline Gender & 1.46 & 0.57 & 3.71 & 0.426 \\
\hline Age & 0.95 & 0.92 & 0.99 & 0.014 \\
\hline Education & 1.36 & 0.87 & 2.12 & 0.180 \\
\hline The distance of residence & 1.01 & 0.57 & 1.77 & 0.973 \\
\hline Occupation & 0.87 & 0.67 & 1.14 & 0.314 \\
\hline Marital Status & 0.93 & 0.25 & 3.48 & 0.911 \\
\hline Family assistance & 0.54 & 0.06 & 5.08 & 0.590 \\
\hline Drug side effects & 4.83 & 2.06 & 11.33 & $<0.001$ \\
\hline Family Support & 0.98 & 0.88 & 1.09 & 0.724 \\
\hline Emosional & 0.93 & 0.68 & 1.28 & 0.666 \\
\hline Appreciation & 0.79 & 0.47 & 1.32 & 0.366 \\
\hline Informational & 1.04 & 0.74 & 1.45 & 0.835 \\
\hline Instrumental & 0.99 & 0.76 & 1.28 & 0.933 \\
\hline Nutritional Status & 0.84 & 0.33 & 2.14 & 0.718 \\
\hline
\end{tabular}

Patient's occupation $(\mathrm{OR}=0.87 ; 95 \%$ $\mathrm{CI}=0.67$ to $1.14 ; \mathrm{p}=0.314)$, patient's marital status $(\mathrm{OR}=0.93 ; 95 \% \mathrm{CI}=0.25$ to $3.48 ; \mathrm{p}=0.911)$, family income $(\mathrm{OR}=0.54$; 95\% CI= 0.06 to $5.08 ; \mathrm{p}=0.590$ ), emotional support $(\mathrm{OR}=0.93 ; 95 \% \mathrm{CI}=0.88$ to 1.09; $\mathrm{p}=0.724)$, support for awards $(\mathrm{OR}=$ $0.79 ; 95 \% \mathrm{CI}=0.47$ to $1.32 ; \mathrm{p}=0.366)$, instrumental support $(\mathrm{OR}=0.99 ; 95 \% \mathrm{CI}=$ 0.76 to $1.28 ; \mathrm{p}=0.933$ ), and nutritional sta-
2.06 to 11.33; $\mathrm{p}<0.001$ ). Age influences the decreases of the success of MDR TB treatment and it was statistically significant $(\mathrm{OR}=0.95 ; 95 \% \mathrm{CI}=0.92$ to $0.99 ; \mathrm{p}=$ o.014). Gender $(\mathrm{OR}=1.46 ; 95 \% \mathrm{CI}=0.57$ to $3.71 ; \mathrm{p}=0.426)$, education $(\mathrm{OR}=1.36 ; 95 \%$ $\mathrm{CI}=0.87$ to $2.12 ; \mathrm{p}=0.18 \mathrm{o})$, distance of residence $(\mathrm{OR}=1.01 ; 95 \% \mathrm{CI}=0.57$ to 1.77 ; $\mathrm{p}=0.973)$, and information support (OR= $0.93 ; 95 \% \mathrm{CI}=0.68$ to $1.28 ; \mathrm{p}=0.666$ ) affect the success of MDR TB but it was not statistically significant. 
patients $(\mathrm{OR}=6.84 ; 95 \% \mathrm{CI}=2.50$ to 18.74 ; $\mathrm{p}<0.001)$ and was statistically significant. The age of patients influences the process of reducing treatment success in MDR TB patients and it was statistically significant $(\mathrm{OR}=0.93 ; 95 \% \mathrm{CI}=0.88$ to $0.97 ; \mathrm{p}=$ 0.004).

Table 4. The results of multivariate analysis of the effect of gender, age, education, occupation, and drug side effects on treatment success in MDR TB patients

\begin{tabular}{lcccc}
\hline \multirow{2}{*}{ Variable } & \multirow{2}{*}{ OR } & \multicolumn{2}{c}{ CI 95\% } & \multirow{2}{*}{ p } \\
\cline { 3 - 4 } & & Lower Level & Upper Level & 0.556 \\
Gender & 0.66 & 0.17 & 2.58 & 0.004 \\
Age & 0.93 & 0.88 & 0.97 & 0.724 \\
Education & 0.90 & 0.52 & 1.58 & 0.485 \\
Occupation & 0.87 & 0.59 & 1.28 & $<0.001$ \\
Drug side effects & 6.84 & 2.50 & 18.74 & \\
\hline
\end{tabular}

Gender $(\mathrm{OR}=0.66 ; 95 \% \mathrm{CI}=0.17$ to 2.58; $\mathrm{p}=0.556)$, education ( $\mathrm{OR}=0.90 ; 95 \%$ $\mathrm{CI}=0.52$ to $1.58 ; \mathrm{p}=0.724)$, and occupation $(\mathrm{OR}=0.87 ; 95 \% \mathrm{CI}=0.59$ to $1.28 ; \mathrm{p}=$ 0.485 ) have an effect on reducing treatment success in MDR TB patients but was not statistically significant.

\section{DISCUSSIONS}

MDR TB is a case of Tuberculosis with resistance to at least 2 types of the most potent anti-tuberculosis drugs, namely Rifampicin and Isoniazid (INH) together or accompanied by other first-line OAT resistance such as Pyrazinamide, Ethambutol and Streptomycin (Ministry health RI, 2014). The success of treatment for drug-resistant TB patients is divided into two, namely patients who successfully complete therapy, namely those whose treatment is complete or cured and do not succeed in completing therapy in accordance with the 2014 MDR Tuberculosis Control Integrated Management Technical Guidelines (Ministry of Health, 2014).

Estimated criteria for MDR-TB sufferers in Indonesia according to the Directorate General of Disease Control and Environmental Health (2014) and the Ministry of Health of RI (2014) include:

1. TB patients who got failed treatment in 2nd category.

2. 2nd category treatment of TB patients which was not converted after 3 months of treatment.

3. TB patients with 2nd category of treatment were not converted after 3 months of treatment.

4. TB patients who got failed treatment in 1st category.

5. TB patients with 1st category of treatment which was not converted.

6. TB patients relapse after OAT therapy in 1st and 2nd category.

7. TB patients failed to get the treatment/ default.

8. It was suspected that TB has a contact history of MDR-TB patients

9. HIV-TB coinfected patients did not respond clinically or bacteriologically to OAT administration (if the initial diagnosis did not use the Molecular Rapid Test (MRT)).

Drug-resistant tuberculosis patients were the patients who were infected by M. tuberculosis bacteria (through a Molecular Rapid Test (MRT) and resistant TB germs that were found (rifampicin) and cannot be treated with conventional OAT, including resistant poly, which was resistant to more than one type of first-line OAT beside Isoniazid (H) and Rifampicin (R) simultaneously, multi drug resistant (MDR) which 
mean resistant to Rifampicin (R) and Isoniazid $(\mathrm{H})$ simultaneously, monoristen, which mean resistance to one of the firstline OAT, pre-Extensive Drug Resistant (XDR) including MDR-TB which was also resistant to one of the Fluoroquinolone OAT groups and at least one of the two types of OAT line injections (Kanamisin, Kapreomisin, and Amikasin). XDR and RR TB were resistant to Rifampicin with or without other OAT resistance which was detected by using the genotype method (rapid test) or phenotypic method (conventional).

A successful treatment was patients who were cured or patients with complete treatment. Patients with cured MDR-TB were patients who complete the therapy according to MDR-TB treatment guidelines without evidence of failure and culture results during the advanced stage which showed negative results at least 3 times in a row with a minimum intervals between the cultures of 30 days. Patients who have successfully completed MDR-TB treatments (complete treatment) were patients who have completed the treatments according to MDR-TB treatment guidelines but did not fulfill the cured or failed definition.

Patients with MDR-TB who did not recover or complete the treatment were divided into two groups, namely the group of patients who died, which in this case was died of any cause during MDR-TB treatment and the group of patients who failed, where MDR-TB treatment was stopped or needed changes in MDR-TB treatment guidelines permanently for two or more MDR-OAT caused by no conversion until the end of the 8th month of the intensive phase or conversion at an advanced stage. The sputum culture became positive on two consecutive examinations after previous conversion was achieved, or there was an evidence of additional resistance to fluoroquinolone class of MDR TB drugs or second-line injection drugs, or because of severe side effects which could stopped the therapy permanently. Lost to follow-up was a patient who was disconnected from treatment for two consecutive months or more.

Side effects of MDR-TB therapy were the side effects which obtained after taking anti MDR-TB drugs and there were no symptoms at previous therapy. Data was obtained from the medical records of drug resistant TB patients. Side effects of therapy variable were included in the type of ordinal scale. The assessment of side effects of MDR-TB therapy was divided into three types according to the Common Terminology Criteria for Adverse Events (CTCAE) version 4.0 in 2009, namely mild/minor, moderate, and severe.

Mild/minor side effects were defined as patients who did not feel the symptoms or symptoms that arised did not interfere the daily activities and did not require special therapy.

Moderate side effects were defined as symptoms that interfere with the patient's daily activities, and it required medical therapy, however, it did not require hospital treatment.

Severe life-threatening side effects that cause death were defined as symptoms that unable the patient to carry out daily activities, it required hospital treatment, termination or replacement of MDR-TB therapy regimen, it also required invasive treatment, and it could lead to mortality.

Family support was the assistances that can be given to other families in the form of goods, services, information, and advice, which made the family members felt comfortable, appreciated, and calm (Taylor, 2006). Family support was highly needed in determining treatment adherence, if family support was given to pulmonary TB 
sufferers, especially MDR-TB, which took longer time (18 months to 2 years), it would motivate the patient to comply with the treatment and take the medication given by the health personnels. A number of other people who have the potential to provide such support were referred to significant others.

According to Friedman (1998) and Bomar (2004), family support was divided into:

1. Emotional support

Communicate the love, care, and trust in family members. The family was considered as a safe and peaceful place for rest and recovery, and could help in mastering the emotions. This type of support was applied by involving expressions of empathy, caring for someone in order to provide a feeling of comfort, and making the individuals to feel better. Individuals regained self-confidence, feel owned and feel loved when they experienced stress. In this case, people who felt that they got this type of social support would feel relieved because they were noticed, got advice or a pleasant impression on themselves.

\section{Instrumental support}

Helping people directly include giving money and house work. This instrumental support referred to the provision of goods or services that can be used to solve practical problems. Taylor (2006) stated that the provision of instrumental support include the provision of financial support and the provision of other goods and services. This type of support was relevant for low economic circles. Family was a source of practical and concrete helps, including the health of TB patients which in this case were the adherence of TB patients in treatment, rest, and TB patients did not feel tired.

3. Information support
The aspects of this support were to give advice, suggestions, instructions, and information. The functions of a family were as a collector and disseminator of information about the world. The family also explained about giving advice, suggestions, and information that can be used to reveal a problem. The benefit of family support was that it can suppress the emergence of a stressor because the information provided can contribute to specific suggestions to individuals. For example, by providing advices regarding the importance of the treatment and the consequences of not adhering to the medication.

\section{d. Appreciation support}

This type of support occurred through expressing positive appreciation for the individual, good encouragement or agreement with the ideas or feelings of other individuals. In this case, the family acted as a guidance for feedback, guiding and solving the problems, and as a source and validator of family identities. They also helped people to learn about themselves and being someone in the same situation or similar experiences, similar in various important ways or made them feel supported by various ideas and feelings. The assessment of nutritional status in this study used the Body Mass Index (BMI) classification in Indonesia.

\section{Table 5. BMI Classification in}

\section{Indonesia}

\begin{tabular}{lc}
\hline \multicolumn{1}{c}{ Category } & BMI \\
\hline Skinny & $<17$ \\
Normal & $17-25$ \\
Fat & $25.1-27$ \\
Obesity & $\geq 27$ \\
\hline \multicolumn{2}{c}{ Source : Health Department of Republic of } \\
\multicolumn{2}{c}{ Indonesia, 2010 }
\end{tabular}


1. The Relationship between Age and Successful Treatment of MDR-TB Patients

Descriptively, it can be seen that patients who have a risk of failure/mortality with an average age group of $48.42 \pm 14.88$ and those who recovered with an average age of $40.22 \pm 12.41$. From the result of this study, it was known that the variable that influence the success of MDR-TB treatment was age variable with the score of $\mathrm{OR}=$ $0.96 ; 95 \% \mathrm{CI}=0.92$ to 0.99 ), and the score of $\mathrm{p}=0.014$, therefore, the older the MDRTB sufferers, the more likely to have a risk of failure/death/drop out. This showed that the younger the age of MDR-TB sufferers, the more successful the treatment. This was in accordance with a study of Anderson et al., (2012) which stated that age variable was related to the success of MDR-TB treatment $(\mathrm{OR}=1.00 ; \mathrm{p}<0.001)$. Other study revealed that increased age has a tendency to experience irregularity in taking medication.

This was because older age needed additional support to access TB treatment (Wu et al., 2009). This condition certainly limited the ability of patients to came and took medication regularly at the Community Health Center. A study done by Ibrahim et al., (2014) found that there was no significant relationship of $\geq 35$ years old age group and the success of treatment (OR= 0.79; 95\% CI= 0.34 to 1.44 ).

2. The Relationship between Gender and Successful Treatment of MDRTB Patients.

Statistically, there was no significant effect of gender on the success of MDR-TB treatment with a score of $\geq 35$ years for the success of treatment $(\mathrm{OR}=0.65 ; 95 \% \mathrm{CI}=$ 0.27 to $1.74 ; p=0.426)$. This was in accordance with a study done by Anderson et al., (2012) which stated that there was no relationship between gender variable and the success of treatment $(\mathrm{OR}=1.46 ; 95 \% \mathrm{CI}$ $=0.76$ to $2.85 ; \mathrm{p}=0.256$ ).

Previous study which stated that women were more likely to find health care and tend to be more obedient to treatment with DOTS compared to men (Wu et al., 2009). Different opinions were obtained from study in Africa, Bangladesh and Syria which stated that married women tended to ask permission from their husbands to come to health services for TB treatment (Ibrahim et al., 2014).

3. The Relationship between Level of Education and Successful Treatment of MDR-TB Patients.

Educational level could increase the success of the treatment of MDR-TB patients by 1.36 times $(\mathrm{OR}=1.36 ; 95 \% \mathrm{CI}=0.87$ to 2.12 ; $\mathrm{p}=0.180$ ) even though it was statistically insignificant. The result was not in accordance with the previous study done by Kondoy et al., (2014) which stated that there was a relationship between level of education with treatment compliance which increased the success of TB treatment.

4. The Relationship between the Distance to Health Facility and Successful Treatment of MDR-TB Patients.

The distance of MDR-TB patients' residences was not related to the success of patient treatment $(\mathrm{OR}=1.01 ; 95 \% \mathrm{CI}=0.57$ to 1.77 ; $\mathrm{p}=0.973$ ). The result was not in accordance with a previous study done by Takarinda et al., (2015) which stated that the time taken by a patient from a residence to a health facility was significantly associated with a delay in TB treatment that could lead to failure treatment $(\mathrm{OR}=0.47 ; 95 \% \mathrm{CI}=0.24$ to $0.94 ; \mathrm{p}=0.032)$.

\section{The Relationship between Employ- ment and Successful Treatment of MDR-TB Patients.}

Patients who have employment reduced the success of treatment in MDR-TB $(\mathrm{OR}=$ 
Journal of Epidemiology and Public Health (2017), 2(1): 45-57

https://doi.org/10.26911/jepublichealth.2017.02.01.05

$0.87 ; 95 \% \mathrm{CI}=0.67$ to $1.14 ; \mathrm{p}=0.314)$. This was in accordance with previous study which stated that patients' employment status was not related to irregularity in taking medication $(\mathrm{OR}=1.60 ; 95 \% \mathrm{CI}=0.66$ to 3.70) (Ibrahim et al., 2014).

Similar study which was done by Kuchukhidze et al., (2014) revealed that there was no relationship between employment and drop out cases in TB treatment. Other study also stated that there was no relationship between employment and treatment adherence of TB patients (Kondoy et al., 2014). A study done by Aibana et al., (2017) stated that employment has a significant relationship with the success of treatment for MDR-TB sufferers.

\section{The Relationship between Marital Status and Successful Treatment of MDR-TB Patients.}

In this study, there was no relationship between marital status and the success of treatment for MDR-TB sufferers $(\mathrm{OR}=$ $0.93 ; 95 \% \mathrm{CI}=0.25$ to $3.48 ; \mathrm{p}=0.911)$. this was in accordance with the results of previous study which stated that marital status was not related to DO cases of TB patients (Kuchukhidze G et al., 2014).

\section{The Relationship between Family Assistance and Successful Treat- ment of MDR-TB Patients.}

In this study, family assistance was not related to the success of treatment $(\mathrm{OR}=1.85$; $95 \% \mathrm{CI}=0.19$ to $17.43 ; \mathrm{p}=0.590$ ). Based on the results of direct interviews conducted by the studyers to patients, it showed that the success of patients' treatment was due to the big desire to recover or personal motivation of the patient so that the presence of family assistance did not affect the success of treatment.

This was not in accordance with the results of previous studies which stated that MDR TB patients need social support to improve their quality of life. Good relation- ships in the family affected the success of treatment (Morris et al., 2013).

\section{The Relationship between Drug Side Effects and Successful Treat- ment of MDR-TB Patients}

Drug side effects were significantly associated with successful treatment of MDR TB patients, with the score of $p=0.001$ in severe side effects and moderate side effects $(\mathrm{OR}=0.04 ; 95 \% \mathrm{CI}=0.01$ to $0.24 ; \mathrm{p}<0.001)$.

This was in accordance with a study done by Deshmuckh et al. (2015), which stated that there were many factors which affect the adherence to treatment of MDRTB patients, including the presence of drug side effects experienced by MDR-TB patients. Another study also mentioned that drug side effects affected the quality of life of MDR-TB patients (Zai et al., 2010).

\section{The Relationship between Family Support and Successful Treatment of MDR-TB Patients}

Family supports, including emotional support $(\mathrm{OR}=0.89 ; 95 \% \mathrm{CI}=0.567$ to 1.42 ; $\mathrm{p}=0.65)$, appreciation support $(\mathrm{OR}=1.04$; $95 \% \mathrm{CI}=0.54$ to $2.03 ; \mathrm{p}=0.90$ ), information support $(\mathrm{OR}=1.16 ; 95 \% \mathrm{CI}=0.75$ to $1.78 ; \mathrm{p}=0.49$ ), and instrumental support $(\mathrm{OR}=1.01 ; 95 \% \mathrm{CI}=0.69$ to $1.45 ; \mathrm{p}=0.985)$ were not related to the success of MDR-TB treatment. This was not in accordance with a study done by Tupasi et al., (2016) which stated that there was a relationship between family support and the possibility of drop out in MDR-TB patients (OR= 0.92; 95\% $\mathrm{CI}=0.85$ to $1.00 ; \mathrm{p}=0.047)$. Similar to a study conducted by Deshmuckh et al., (2015) which stated that one of the factors that affect the success of MDR-TB treatment was family support. 
10. The Relationship between Nutritional Status and Successful Treatment of MDR-TB Patients.

Nutritional status of MDR-TB patients was not related to the success of treatment $(\mathrm{OR}=2.07 ; 95 \% \mathrm{CI}=0.47$ to $3.02 ; \mathrm{p}=$ 0.718). This was in accordance with a study done by Tupasi et al., (2016) which stated that there was no relationship between nutritional status (Body Mass Index) and the possibility of drop out in MDR-TB patients $(\mathrm{OR}=1.17 ; 95 \% \mathrm{CI}=0.7$ to 1.94 ; $\mathrm{p}=0.55)$.

The success of treatment in Tuberculosis Multi Drug Resistant (MDR-TB) patients was affected by age and drug side effects, especially severe and moderate, while minor /normal side effects have no effect on the success of treatment. Likewise with other independent variables that did not show a relationship with the success of treatment, which were gender, education, distance to health facilities, employment, marital status, family assistance, family support, and nutritional status.

\section{REFERENCES}

Aibana O, Bahmaha M, Kraisuk V, Rybak N, Flanigan, TP, Petrenko V (2017). Risk Factors For Poor Multidrugresistant Tuberculosis Treatment Outcomes in Kyiv Oblast, Ukraine. Bio Med Central Infectious Disease, 17 (124): 1-7.

Anderson LF, Watson JP, Tamne S, Cohen T, Mitnick T, Drobniewski F, Abubakar I (2013). Treatment outcome of multi-drug resistant tuberculosis in the United Kingdom: retrospectiveprospective cohort study from 2004 to 2007. European Surveillance, 18(40): 1-10.

Avong YK, Isaakidis $\mathrm{P}$, Hinderaker SG, Van den Bergh R, Ali E, Obembe BO (2015). Doing No Harm? Adverse
Events in A Nation-Wide Cohort of Patients with Multidrug-Resistant Tuberculosis in Nigeria. Plos One, 10: 1-5.

Burhan E (2010). Tuberkulosis Multi Drug Resistance (TB-MDR). Majalah Kedokteran Indonesia, 6o(12): 535-536.

Chen S, Huai P, Wang X, Zhong J, Wang X, Wang K (2013). Risk Factors for Multidrug Resistance Among Previously Treated Patients with Tuberculosis in Eastern China: a Case-Control Study. International Journal of Infectious Diseases, 17: e1116-e1120.

Deshmukh R, Dhande DJ, Sachdeva KS, Sreenivas A, Kumar AMV, Satyanarayana S (2015). Patient and Provider Reported Reasons for Lost to Follow Up in MDRTB Treatment: a Qualitative Study from a Drug Resistan TB Centre in India. Plos One, 10, 1-11.

Dhingra VK, Rajpal S, Mittal A, Hanif M (2007). Outcome of Mlti-Drug Resistant Tuberculosis Cases Treated Cases Treated by Individualized Regimens at a Tertiary Level Clinic. Indian Journal of Tuberculosis.15-21.

Direktorat Jendral Pengendalian Penyakit dan Penyehatan Lingkungan (2014). Pedoman Nasional Pengendalian Tuberkulosis. Kementerian Kesehatan Republik Indonesia.

Finlay A, Lancaster J, Hotlz Timothy H, Weyer K, Miranda A, Van Der Walt M (2012). Patient and Provider-Level Risk Factors Associated with Default from Tuberculosis Treatment, South Africa, 2002: a Case-Control Study. Bio Med Central Public Health, 56(12): 1-12.

Franke MF, Appleton SC, Bayona J, Arteaga F, Palacios E, Llaro K (2008). Risk Factors and Mortality Associated with Default from Multidrug-Resistant Tuberculosis Treatment. National Insti- 
Journal of Epidemiology and Public Health (2017), 2(1): 45-57

https://doi.org/10.26911/jepublichealth.2017.02.01.05

tutes of Health Public Access, 46(12): 2-14.

Gadallah MA, Mokhtar A, Rady M, ElMoghazy E, Fawzy M, Kandil SK (2015). Prognostic Factors of Treatment Among Patients with MultidrugResistant Tuberculosis in Egypt. Journal of the Formosan Medical Association, 20: 1-7.

Gupta RD (2016). MDR-TB: An emerging burden for Bangladesh. South East Asia Journal of Public Health, 53-53.

Healy S, Dietrich S, Nyang Wa BT, Ducros $P$ (2012).Public Health Advocacy for The Berlin Declaration on Tuberculosis in the Former Soviet Union: The View of Medecins Sans Frontieres. European Journal of Microbiology and Immunology 2(4): 282-286.

Holtz TH, Sternberg M, Kammerer S, Laserson KF, Riekstina V, Zarovska E (2006). Annals of Internal Medicine Article Time to Sputum Culture Conversion in Multidrug-Resistant Tuberculosis: Predictor and Relationship to Treatment Outcoma. Annals of Internal Medicine, 144(9): 650-659.

Ibrahim LM, Hadejia IS, Ngruku P, Dankoli R, Waziri NE, Akhimien MO (2014). Factors associated with interruption of treatment among Pulmonary Tuberculosis patients in Plateau State, Nigeria 2011. The Pan African Medical Journal, 7: 1-8.

Kondoy PPH, Rombot DV, Palandeng HMF, Pakasi TA (2014). Faktor-faktor yang berhubungan dengan kepatuhan berobat pasien Tuberkulosis Paru di Lima Puskesmas di Kota Manado. Jurnal Kedokteran Komunitas dan Tropik, 2(1): 1-8.

Kuchukhidze G, Kumar AMV, de Colombani P, Khogali M, Nanava, Blumberg HM (2014). Sort It Supplement: TB in Eastern Europe, 2012-2014. Risk fac- tors associated with loss to follow-up among multidrug-resistant tuberculosis patients in Gorgia.Public Health Action, 4(2): 541-546.

Milanov V, Falzon D, Zamfirova M, Varleva T, Bachiyska E, Koleva A (2015). Factors associated with treatment success and deaht in cases with multidrugresistant tuberculosis in Bulgaria, 2009-2010. International Journal of Mycobacteriology, 4: 131-137.

Munir SM, Nawas A, Soetojo DA (2010). Pengamatan Pasien Tuberkulosis Paru dengan Multidrug Resistant (TB-MDR) di Poliklinik Paru RSUP Persahabatan. Jurnal Respirologi Indonesia, 30: 92-102.

Pant R, Pandey KR, Joshi M, Sharma S, Pandey T, Pandey S. (2009). Risk Factor Assessment of Multi Drug Resistant Tuberculosis. Journal Nepal Health Res Counc, 7(15): 89-92.

Rodriguez M, Monedero I, Caminero JA, Encarnacion M, Dominguez Y, Acosta I (2013). Successful management of multidrug resistant tuberculosis under programme conditions in the Dominican Republic. International Journal Tuberculosis Lung Disease, 17(4): 520-525.

Takarinda KC, Harries AD, Nyathi B, Ngwenya M, Mutasa-Apollo M, Sandi C (2015). Tuberculosis treatment delayes and associated factors within the Zimbabwe national tuberculosis programme. BMC Public Health, 15(29): 1-12.

Tripathi UC, Nagaraja SB, Tripathy JP, Sahu SK, Parmar M, Rade K (2015). Follow-up examinations: are multidrug-resistant tuberculosis patients in Uttar Pradesh India, on track? Public Health Action, 5(1): 59-64.

Tupasi TE, Garfin AMCG, Kurbatova EB, Mangan JM, Orillaza-Chi R, Naval LC 
Widyasrini et al./ Factors Affecting the Success of Multi Drug Resistance

(2016). Factors Associated with Loss to Follow-up during Treatment of MutiDrug-Resistant Tuberculosis the Phillipines, 2012-2014. Emerging Infectious Diseases, 20(3): 491-502.

WHO (2015). Global Tuberculosis Report. Switzerland.
Zai S, Haroon T, Mehmood KT (2010). Socioeconomic Factors Contributing to Multidrug-Resistant Tuberculosis (MDR-TB). Journal Biomed Science and Respirology, 2(4): 279-283 